\title{
DIFFERENTIATION OF THE OLFACTORY EPITHELIUM IN SHEEP IN ONTOGENESIS USING SCANNING ELECTRON MICROSCOPY
}

\author{
F. TICHÝ ${ }^{1}$, D. HORKÝ⿱ ${ }^{2}$ and I. MIŚSEK ${ }^{3}$ \\ 1, 3 - Department of Anatomy, Histology and Embryology, Faculty of Veterinary Medicine, \\ University of Veterinary and Pharmaceutical Sciences, 61242 Brno \\ 2 - Department of Histology and Embryology, Faculty of Medicine, Masaryk University, $60200 \mathrm{Brno}$
}

Received October 3, 1994

Accepted March 30, 1995

\begin{abstract}
T i c h ý F., D. H o r k ý, I. M í ̌ e k : Differentiation of the Olfactory Epithelium in Sheep in Ontogenesis using Scanning Electron Microscopy. Acta vet. Brno 1995, 64:71-77.

The method of scanning electron microscopy was used to study the differentiation of the olfactory epithelium and the formation of the surface of the olfactory epithelium of sheep on the 74th and 79th days of prenatal period, on the day of birth, 30 days after birth and in an adult animal of 730 days of age.

From the 74th day of i.u. development, the olfactory endings on the surface of the olfactory epithelium were found to be on different levels of development. Their amount gradually increased prior to birth as did the amount of olfactory cilia growing out of these olfactory endings. The cilia were formed first, in the range of proximal segments; distal segments of cilia appeared later, in dependence on the degree of differentiation of the olfactory endings.

No microvilli were yet formed on the apical segments of the sustentacular cells of a 74-day old foetus. They began to differentiate after the 79th day of i.u. development and most of them were not formed until the immediate perinatal period. In the postnatal period the amount of newly formed olfactory endings decreased, but the number and length of olfactory cilia continued to increase. Areas of regenerating olfactory epithelium and individual differentiating olfactory endings could also be observed in an adult animal.
\end{abstract}

Differentiation, microvilli, olfactory epithelium, olfactory cilia, sheep

Many authors studied the structure and ultrastructure of the olfactory epithelium using light microscopy as well as transmission and scanning electron microscopy. In literature we can find detailed data about the structure of this epithelium in fish and amphibians (F a rb m an and Ge ste land 1974; U sukura and Y a m a d a 1978; Fr ance s chini and C i a $\mathrm{n}$ i 1991), in birds (G r a z i a d e i and B a n n is te r 1967; B r e i p o h land Fe r n a n de z 1977) and particularly in various mammals (B r e i p o h l1972; A n d r e w s 1975; Y a m a m o t o 1976; M e n c o et al. 1976, 1978; M e n c o 1977, 1988; M e nd o z a et al. 1992; and others) and man (B u s u t t i 1 et al. 1977; M o r a $\mathrm{n}$ et al. 1982; and others). In numerous communications the epithelium was compared in various mammals or vertebrates (G r a z i a d e i 1971a, 1973ab, 1974, 1975; B r e i p o h l et al. 1974ab; K e r j a s c h k i 1978; G e t c h e 11 1986; and others).

The basic classification of cells of the olfactory epithelium is similar in all the hitherto studied animal species. Most of the morphological studies involve descriptions of the olfactory receptors proper and of the sustentacular cells (M o u $\mathrm{lt}$ o $\mathrm{n}$ and B e i d l e r 1967; $\mathrm{G} \mathrm{r} \mathrm{a} \mathrm{z} \mathrm{i} \mathrm{a} \mathrm{d} \mathrm{e} \mathrm{i} \mathrm{1973a;} \mathrm{M} \mathrm{e} \mathrm{n} \mathrm{c} \mathrm{o} \mathrm{1977;} \mathrm{and} \mathrm{others),} \mathrm{particularly} \mathrm{the} \mathrm{distribution} \mathrm{of} \mathrm{olfactory}$ endings and the structure of the deflecting olfactory cilia (S e i f e r t 1970; $\mathrm{M}$ e $\mathrm{n}$ c o et al. $1976 ; \mathrm{M}$ e n c o 1977, 1988). The olfactory cilia, namely their distal segments are considered to be the bearers of receptor loci (K e r j a s c h k i and Hö r a n d n e r 1976; G e t c h ell 1986).

In literature considerable attention was devoted to the description of apical segments of sustentacular cells ( $\mathrm{S}$ e i f e r t 1970; M e n c o 1977) particularly to the structure and function of their microvilli (K e r j a s c h k i and $\mathrm{H}$ ö r a n d n e r 1976; M e n c o et al. 1978). The function of the sustentacular cells is usually compared with the function of gliocells (B r e i p o h l et al. 1974b). Some authors (M o u $1 \mathrm{t}$ o $\mathrm{n}$ and 
B e i d l e r 1967; Y a m a m o t o 1976) also reported that these cells have a secretory function.

Numerous studies have been devoted to the origin, development and regeneration of the olfactory epithelium (B r e i p o h 1 1972; B r e i p o h 1 et al. 1973b, 1974b; $\mathrm{C} \mathrm{u} \mathrm{s} \mathrm{c} \mathrm{h} \mathrm{i} \mathrm{e} \mathrm{r} \mathrm{i} \mathrm{and} \mathrm{B} \mathrm{a} \mathrm{n} \mathrm{n} \mathrm{i} \mathrm{s} \mathrm{t} \mathrm{e} \mathrm{r} \mathrm{1975;} \mathrm{and} \mathrm{others).} \mathrm{Basal} \mathrm{cells} \mathrm{are} \mathrm{generally} \mathrm{considered}$ to be the initial elements for the development of individual types of cells of the olfactory epithelium, even though the existence of a "reserve" cell population is also possible ( $\mathrm{C} \mathrm{u} \mathrm{s} \mathrm{c} \mathrm{h} \mathrm{i} \mathrm{e} \mathrm{ri} \mathrm{and} \mathrm{B} \mathrm{a} \mathrm{n} \mathrm{n} \mathrm{i} \mathrm{s} \mathrm{t} \mathrm{e} \mathrm{r} \mathrm{1975;} \mathrm{M}$ or a $\mathrm{n}$ et al. 1982). The regeneration of the olfactory epithelium, including the olfactory receptors, is permanent and occurs also in the postnatal period (K e r j a s c h k i and H ö r a n d n e r 1976; M e n c o 1977; and others).

There are relatively few data of this kind in domesticated mammals. The olfactory epithelium was described in greater detail only in adult sheep ( $\mathrm{K} \mathrm{r}$ a t z i n $\mathrm{g} \mathrm{1970;}$ M e n c o 1977) and cattle (M e n c o et al. 1976, 1978).

\section{Materials and Methods}

Material for studies of the structure of the olfactory epithelium in REM was taken from the 3rd endoturbinal of the olfactory labyrinth of sheep foetuses aged 74 and 79 days of intrauterine development, from lambs on the day of birth and within $\mathbf{3 0}$ days of birth, always from three animals of the given age. In order to obtain a complete picture and to be able to compare the results, samples were also taken from adult sheep aged 730 days.

The age of the foetuses was determined according to E v a n s and S a c k (1973) and was based on the length between the vertex and tail root.

The samples were immediately rinsed in three baths of physiological solution for 15 minutes and fixed with 1.33 $\mathrm{mol} / \mathrm{l}$ of formol. The material was then dehydrated in an increasing series of alcohol of $0.6 \mathrm{mmol} / \mathrm{l}, 0.7 \mathrm{mmol} /, 0.96$ $\mathrm{mmol} / /$ and $1.0 \mathrm{mmol} / \mathrm{l}$ concentrations and transferred into anhydrous acetone.

Dehydration was terminated using the method of desiccation at the critical point and the samples were gold-coated in the BALZERS SCD 040 sputtering apparatus. This material was examined and photographed in the Tesla BS 300 scanning electron microscope.

\section{Results}

Sheep foetus aged $74 d a y s$

The dividing line between the respiratory and olfactory regions of this age category was a continuous strip of 10-15 $\mu \mathrm{m}$ long formations, deflecting in tufts from the apical part of the epithelium cells (Plate XXVIII., Fig. 1).

A large part of the surface of the olfactory mucosa was covered with a layer of fine granular secretion which camouflaged the underlying structures. In the more rostral regions of the regio olfactoria this covering was not so dense, distinctly showing the structure of the epithelium surface.

The surface of the olfactory epithelium was broken up into numerous spherical differentiating olfactory endings of various sizes $(1-4 \mu \mathrm{m})$, frequently covered with many oval- shaped bodies $0.1-0.2 \mu \mathrm{m}$ in size (Plate XXVIII., Fig. 2). In some places, formations of 7 and more /um can be found, mostly cupola- shaped (Fig. 2), sometimes slightly lobe-shaped.

The thick superficial network consisted, on the one hand, of thicker, proximal segments of cilia 2-3 $\mu \mathrm{m}$ long which in some cases deflected radially from one dendrite ending of the sensory cell (Fig. 2), and of considerably longer, less numerous fibres of smaller diameter which represented the distal segments of olfactory cilia, on the other. Sporadical tufts of ca 1-2 $\mu \mathrm{m}$ long microvilli of the sustentacular cells were found on the surface of the olfactory epithelium.

In some parts of the olfactory epithelium surface, the outlet ducts of gll. olfactoriae opened irregularly into the shallow pits. 
Sheep foetus aged 79 days

The shape of the intermediary part between the respiratory and olfactory region of the nasal mucosa was a cylindrical prominence running transversely along the periphery of the 3rd endoturbinal.

The surface of the regio olfactoria was again broken up into a thick fibrous network and above were numerous spherical elevations of differentiating olfactory endings of about 2-4 $\mu \mathrm{m}$. The endings were covered with various amounts of small light globular formations $1-0.3 \mu \mathrm{m}$ in diameter which cause the carunculous appearance of the surface (Plate XXIX., Fig. 3).

Shorter (ca 2-3 $\mu \mathrm{m}$ ) and thicker (ca $0.4 \mu \mathrm{m}$ ) proximal cilium segments, and thinner $(0.2-0.3 \mu \mathrm{m})$ and long fibres (as long as $24 \mu \mathrm{m})$ corresponding to the distal segments protruded sporadically from some of the smaller endings of sensory cells of a diameter of approximately 1-1.5 $\mu \mathrm{m}$ (Fig. 3). The surface of both structures was mostly smooth, even though minute prominences do sporadically occur (Fig. 3).

In the spaces between the individual developing olfactory endings was a dense network of fine fibres mostly deflecting from the typical club-shaped endings of about $1 \mu \mathrm{m}$. Small, sparcely dispersed, globular corpuscles were found in this network along with the detritus $(0.2-0.3 \mu \mathrm{m})$.

\section{Lamb, aged 1 day}

The dividing line between the olfactory and respiratory region of the nasal mucose was sharply indicated.

The surface of the epithelium of the regio olfactoria was covered with a virtually continuous layer of tiny microvilli of sustentacular cells which protruded in tufts from their apical sections ( Plate XXIX., Fig. 4). In some cases the microvilli formed extensive, large bushy formations of 6-7 $\mu \mathrm{m}$ (Fig. 4). On the greater part of the surface these structures completely covered the deeply placed thicker and variously long olfactory cilia deflecting from the club-shaped widened endings of the sensory cells. Such endings can be observed only in the artificially formed fissures of the epithelium (Fig. 4). The spherical prominences described in all the previous stages of development and representing the hitherto non-differentiated endings of olfactory neurones occurred only sporadically and they were about 2-3 $\mu \mathrm{m}$ large (Fig. 4). Thin fibrous distal segments of cilia, the length of which was very difficult to determine due to the unevenness of the epithelial surface, were found to occur sporadically also in intact areas of the mucosa where they intertwined among the tufts of minute prominences.

The outlet ducts of gll. olfactoriae opened into shallow pits sparcely dispersed as individual small openings of ca $1 \mu \mathrm{m}$ in diameter. Remains of the secretion were often found around them, sticking together the fibrous structures of the epithelial surface.

\section{Lamb aged 30 days}

The dividing line between both types of nasal mucosa was the same as in the preceding stage od development.

The olfactory epithelium was covered with a discontinuous layer of globular or oval-shaped light-coloured formations of various sizes (1-5 $\mu \mathrm{m}$ and more) consisting of numerous small fibrous structures stuck together by the mucin (Plate XXIX., Fig. 5), obviously microvilli of the sustentacular cells. In some parts the thick tangle of fibres which can be observed among the described formations contained small (ca $0.3 \mu \mathrm{m})$ globular corpuscles and detritus (Fig. 5). This network was formed by proximal and distal segments of olfactory cilia some of which deflected radially from the apical endings of the sensory cells (Fig. 5).

The outlet ducts of gll. olfactoriae are comparable with the 1-day old lamb. 
Adult sheep, aged 730 days

The appearance of the surface of the olfactory epithelium was somewhat different in the rostral and caudal regions.

The more rostral sections of the epithelium, particularly immediately behind the inexpressive line dividing the regio respiratoria from the regio olfactoria were covered with a dense tangle of fibrous structures which looked like elongated cones and are $20 \mu \mathrm{m}$, or more, long ( Plate XXX., Fig. 6). In many cases we observed a radial deflection of these fibres from one ending of the sensory cell (Fig. 6). The direction of the individual fibres was different, however, the rostrocaudal direction prevailed.

These fibrous formations were olfactory cilia, their deflecting part (proximal segment) usually ca $0.1-0.2 \mu \mathrm{m}$ in diameter, the distal segment was distinctly thinner, in many cases ended in a terminal mallet-shaped widening. Contacts between the distal segments were sporadic (Fig. 6). In this dense network there were numerous small globular formations smaller than $0.5 \mu \mathrm{m}$ and exceptionally also large spherical prominences (3-4 $\mu \mathrm{m})$ which protruded above the surrounding surface (Fig. 6) and corresponded with the olfactory cells in their differentiating endings.

In the caudal part of the regio olfactoria there were fairly extensive areas of olfactory epithelium and on the surface were relatively few of the above described fibrous structures. Characteristic of these areas was the presence of small club-like formations (1-2 $\mu \mathrm{m})$ (Plate XXXI., Fig. 7) which were the endings of dendrites of sensory cells and from which 10 cilia, on average, 1-3 $\mu \mathrm{m}$ long, protruded (Fig. 7). More frequently than in the rostral regions, in the caudal part large spherical prominences of developing olfactory endings of 3-4 $\mu \mathrm{m}$ can be found, frequently covered with small globular particles or short outgrowths (Fig. 7).

\section{Discussion}

In all the investigated developmental stages the surface of the olfactory epithelium was broken up into fine fibrous structures and small prominences, the amount of which increased with increasing age. Data had been presented earlier which confirm the continuous development of the olfactory epithelium both in the postnatal (B r e i p o h 1 1972; B r e i p o h l et al. 1973a, 1974a; B r e i p o h 1 and Fer n a n d e z 1977; M e n c o 1977 and others) and prenatal (C u s c h i e r i and B a n n i s t e r 1975; K e r j a s c h k i and H ö r a n d n e r 1976; and others) period. A typical structural character of the developing olfactory epithelium appears to be the occurrence of spherical or cupola-like prominences of ca 3 /um in diameter. Similar formations were found, for instance, also in hamster embryos (W a t e r $\mathrm{m}$ a $\mathrm{n}$ and $\mathrm{M}$ e $1 \mathrm{l}$ e $\mathrm{r}$ 1973), but also on the surface of the olfactory mucosa of adult cattle (M e n c o 1977). In accordance with the above authors we must state that these are the newly forming endings of dendrites of sensory cells not yet equipped with cilia.

Many of the newly formed olfactory endings during the investigated intrauterine period do not grow continually and from the 79th day the occurrence of the individual segments of cilia is more numerous. In our opinion it is because the development of apical structures of the olfactory neurones runs in certain time intervals when their periodic changes take place; this occurs also in adults, as was confirmed by findings of other authors (M o u $1 \mathrm{t}$ o $\mathrm{n} \mathrm{1974,}$ 1975; M e n c o 1977; and others).

On the surface of the developing olfactory endings, small, light-coloured, globular formations, were regularly found, particularly numerous on the 79th day of development. On the other hand, however, optically similar structures are sometimes located on the already existing cilia. M e n c o (1977) indicated similar findings as "ciliary sacs", that is, recesses of the ciliary membrane. They could also be indicated as vesicles, various numbers of which had been seen in the transmission electron microscope (M e n c o 1977) and which were 
laid in a tangle of cilia and microvilli on the surface of the olfactory epithelium. Along with this, a system of fibrous structures was observed on the surface of the developing olfactory epithelium which more or less filled up the spaces between the prominences. They could be previously formed cilia which are continuously regenerated. In his communication, $\mathrm{M} \mathrm{e} \mathrm{n} \mathrm{c} \mathrm{o} \mathrm{(1988)} \mathrm{indicated} \mathrm{a} \mathrm{similar} \mathrm{possibility} \mathrm{in} \mathrm{the} \mathrm{development} \mathrm{of} \mathrm{the} \mathrm{olfactory} \mathrm{mucosa}$ of rats.

Also the sporadical occurrence of relatively large ( $7 \mu \mathrm{m}$ and more) sac-like or copula-shaped formations on the 74th day of development obviously corresponding with the differentiating apical sections of sustentacular cells the surface of which is not divided into a system of microvilli was remarkable. Since these structures we not found in the other developmental stages, we admit that they could be of artificial origin. Typical microvilli of sustentacular cells occur sporadically as early as the 74th day of development but their highest occurrence was not observed until after birth, in the 1-day old lamb. These findings correspond to the opinions of some other authors that the maturation of sustentacular cells does not occur until the period immediately before birth (C u s c h i e r i and B a n n i s te r 1974, 1975).

Most of the olfactory cilia protruding from the olfactory endings of the sensory cells, correspond to the proximal segments in the foetal stage. In this connection we cannot completely exclude that their distal parts were not damaged or broken off during technical processing of the material, however, we assume that in fact they are newly developed cilia where the distal segment had not yet been formed. The long fibrous formations which correspond to the distal segments of the cilia were observed more frequently after the 79th day; however, the exact determination of their total length is not possible, what is in accordance with previously presented opinions (S e i f e r t 1970; $M$ e $n$ c o 1977). In the adults, contacts among the distal segments of olfactory cilia were found. The existence of these contacts is common in other animal species (M e n c o et al. 1978; $\mathrm{U} \mathrm{s} \mathrm{u} \mathrm{k} \mathrm{u} \mathrm{r} \mathrm{a} \mathrm{and}$ Y a m a d a 1978 and others). In our opinion, more remarkable is the predominant rostrocaudal orientation of olfactory cilia in the adult sheep. It is our opinion that this is a functional adaptation because most of the receptive sites on cilia membranes are situated in this position due to the flow of aspired air.

Exceptional was the finding of a continuous strip of long fibrous formations on the dividing line between the regio respiratio and the regio olfactoria of the nasal mucosa in a 74-day old foetus. In the other foetal stages this dividing line is very distinct, here there are no similar fibrous structures and they are not mentioned in literature. They are assumed to be a layer of abnormally long cilia of cells of the respiratory epithelium monitored in a certain stage of their movement enabling the passage of the secretion of nasal glands (B r e i p o h 1 1972; M e n c o et al. 1976, 1978; M e n c o 1977) also into the olfactory region.

\section{Conclusions}

The present study describes the process of differentiation of superficial structures of the olfactory epithelium of sheep in various stages of ontogeny. Attention was devoted particularly to the origin and development of olfactory endings, olfactory cilia and the production of microvilli of sustentacular cells. Basing on the present findings it can be concluded that:

1 . The intensity of differentiation of apical segments of olfactory cells varied in the period under study.

2. The largest amount of olfactory endings is developed in the foetal stage but they develop postnatally as well.

3. Distal segments of olfactory cilia occur only sporadically in the foetal period. Most of the observed olfactory cilia in this period correspond with their proximal segments. 
4. Contacts (or ramification) of distal segments of the olfactory cilia occur only sporadically in adult animals.

\section{Diferenciace čichového epitelu ovce v ontogenezi metodou rastrovací elektronové mikroskopie}

Metodou rastrovací elektronové mikroskopie byla studována diferenciace čichového epitelu a utváření čichové sliznice ovce v 74. a 79. dnu intrauterinního (i.u.) vývoje, v den narození, 30 dnủ po narození a u dosplělého jednice stárí 730 dnů.

Bylo zjištěno, že od 74. dne i.u. vývoje se na povrchu cichového epitelu vyskytují cichová zakončení na rủzném stupni vývoje. Jejich množství se $v$ době do narození postupně zvyšuje a zvyšuje se i počet čichových raasinek vyrůstajících z čichových zakončení. Řasinky se vytvářejí nejprve v rozsahu proximálních segmentů, distální segmenty rasinek se objevuji až později v závislosti na stupni diferenciace čichového zakončení.

$\mathrm{Na}$ apikálních úsecích podpůrných buněk u 74 . dnů starého fetu dosud nejsou mikroklky vytvořeny. Tyto se začínají diferncovat od 79 . dne i.u. vývoje a v největší míře jsou vytvoreny až v těsně perinatálním období.

V postnatální periodě se snižuje množství nově se tvơ̌ících čichových zakončení, ale nadále se zvyšuje počet i délka čichových řasinek. Okrsky regenerujícího čichového epitelu i jednotlivá, diferencující se čichová zakončení lze pozorovat i u dospělého jedince.

The presented results are a part of a project supported by the Grant Agency of the Czech Republic No.204/93/0492.

\section{References}

ANDREW P. M. 1974: A scanning electron microscopic study of the extra pulmonary respiratory tract. Am. J. Anat. 139:399-423

BREIPOHL W. 1972: Licht- und elektronenmikroskopische Befunde zur Struktur der Bowmanschen Drusen im Riechepithel der weisen Maus. Z. Zellforsch. 131:329-346

BREIPOHL W., BIJVANK G. J., ZIPPEL H. P. 1973a: Rastermikroskopische Untersuchungen der olfaktorischen Rezeptoren im Riechepithel des Goldfisches (Carassius auratus). Z. Zellforsch. 138: 439-454

BREIPOHL W., MESTRES P., MELLER K. 1973b: Licht- und elektronenmikroskopische Befunde zur Differenzierung des Riechepithels der weissen Maus. Verhandlung der Anatomischen Gesellschaft, Jena 67:443-449

BREIPOHL W., BIJVANK G. J., PFEFFERKORN G. 1974a: Scanning electron microscopy of various sensory receptor cells in different vertebrates. In: Scanning electron microscopy, Vol. 7 (O.Johari and I.Corvin, eds.). Chicago, pp. 557-564

BREIPOHL W., LAUGWITZ H. J., BORNFIELD N. 1974b: Topological relations between the dendrites of olfactory cells and sustentacular cells in different vertebrates. An ultrastructural study. J. Anat. 117:89-94

BREIPOHL W., FERNANDEZ M. 1977: Scanning electron microscopic investigations of olfactory epithelium in the chick embryo. Cell Tiss. Res. 183:105-114

BUSUTTIL A., MORE I. A. R., McSEVENEY D. 1977: A reappraisal of the ultrastructure of the human respiratory nasal mucosa. J. Anat. 124:445-458

CUSCHIERI A., BANNISTER L. H. 1974: The development of the olfactory mucosa in the mouse. Light microscopy. J. Anat. 119:227-286

CUSCHIERI A., BANNISTER L. H. 1975: The development of the olfactory mucosa in the mouse. Electron microscopy. J. Anat. 119:471-498

EVANS H. E., SACK W. O. 1973: Prenatal development of domestic laboratory mammals. Growth curves, external features and selected references. Anat. Histol. Embryol. 2:11-45

FARBMAN A. I., GESTELAND R. C. 1974: Fine structure of olfactory epithelium in the mud puppy. Am. J. Anat. 139:227-244

FRANCESCHINI V., CIANI F. 1991: Lectin histochemical study of olfactory neurons in the eel. Cell Mol. Biol., 37:61-71

GETCHELL T. V. 1986: Functional properties of vertebrate olfactory receptor neurons. Physiol. Rev. 66:772-818

GRAZIADEI P. P. C. 197la: The olfactory mucosa of vertebrates. In: Handbook of sensory physiology. Vol. IV: Chemical senses, part l: Olfaction (L.M.Beidler, ed.), Berlin-Heidelberg-New York: Springer, pp. 27-58

GRAZIADEI P. P. C. 1973a : The ultrastructure of vertebrates olfactory mucosa. In: The ultrastructure of sensory 
organs (I.Friedman, ed.), Amsterdam: North-Holland Publ. Coa, pp. 267-305

GRAZIADEI P. P. C. 1973b: Cell dynamic in the olfactory mucosa. Tiss. Cell 5:113-131

GRAZIADEI P. P. C. 1974: The olfactory organ vertebrates: A survey.In: Essays on the nervous system (R.Bellairs and E.G.Gray, eds.), Oxford: Clarendon Press, pp. 191-222

GRAZIADEI P.P.C. 1975: Application of scanning electron microscopy and autoradiography in the study of olfactory mucosa. In: Methods in olfactory research (D. G. Moulton, A. Turk and J. W. Johnston, Jr., eds.), London: Academic Press, pp. 191-240

GRAZIADEI P. P. C., BANNISTER, L. H. 1967: Some observations on the fine structure of the olfactory epithelium in the domestic duck. Z. Zellforsch. 80:220-228

GRAZIADEI P. P. C., DE HAN, R. S. 1971: The ultrastructure of frog's taste organs. Acta anat. 80:563-603

KERJASCHKI D. 1978: Some freeze-etching data on the olfactory epithelium. In: Olfaction and taste, Vol. VI. (J. LeMagnen and P. MacLeod, eds.), London and Washington: Information Retrieval Ltd., pp. 75-85

KERJASCHKI D., HÖRANDNER H. 1976: The development of mouse olfactory vesicles and their cell contracts: A freeze-etching study. J. Ultrastruct. Res. 54:420-444

KRATZING J. E. 1970: The olfactory mucosa of the sheep. Aust. J. biol. Sci. 23:447-458

MENCO B. P. M. 1977: A qualitative and quantitative investigation of olfactory and nasal respiratory surfaces of cow and sheep based on various ultrastructural and biochemical methods. Communications Agricultural University, Wageningen 77-13, pp. 1-157

MENCO B. P. M. 1988: Prenatal development of rat nasal epithelia. IV. Freeze-fracturing on apices, microvilli and primary and secondary cilia of olfactory and respiratory epithelial cells, and on olfactory axons. Anat. Embryol. (Berlin), 178:309-326

MENCO B. P. M., DODD G. H., DAVEY M., BANNISTER L.-H. 1976: Presence of membrane particles in freeze-etched bovine olfactory cilia. Nature (London) 263:597-599

MENCO B. P. M., LEUNISSEN J.L. M., BANNISTER L. H., DODD G. H. 1978: Bovine olfactory and nasal respiratory epithelium surfaces. Cell Tiss. Res., 193: 503-524

MENDOZA A. S., KRISHNA A., ENDLER J., KÜHNEL W. 1974: Die Regio olfactoria der Fledermaus (Scotophilus heathi). Licht- und elektronenmikroskopische Studien. Ann. Anat. 199:207-211

MORAN D. T., ROWLY J. C., JAFEK B. W., LOWELL M. A. 1982: The fine structure of the olfactory mucosa in man. J. Neurocytol. 11:721-746

MOULTON D. G. 1974: Dynamics od cell populations in the olfactory epithelium. Ann. N. Y. Acad. Sci. 237:52-61

MOULTOND. G. 1975: Cell renewal in the olfactory epithelium of the mouse. In: Olfaction and Taste V., (D.A.Denton and J.P.Coghlan, eds.), Academic Press, New York, pp. 11l-114

MOULTON D. G., BEIDLER L. M. 1967: Structure and function in the peripheral olfactory system. Physiol. Rev. 47:1-52

SEIFERT K. 1970: Die Ultrastruktur des Riechepithels beim Makrosmatiker. Eine elektronenmikroskopische Untersuchung. Normale und Pathologische Anatomie, Heft 21 (W.Bargmann and W.Doerr, eds.), Stuttgart: Georg Thieme Verlag

USUKURA J., YAMADA E. 1978: Observations on the cytolemma of the olfactory receptor cell in the newt. Freeze replica analysis. Cell Tiss. Res. 188:83-98

WATERMAN R. E., MELLER S. M. 1973: Nasal pit formation in the hamster. A transmission and scanning electron microscopic study. Develop. Biol. 34:255-266

YAMAMOTO M. 1976: An electron microscopic study of the olfactory mucosa in the bat and rabbit. Arch. Histol. Jap. 38:359-412. 
Tichý F. et al.: Differentiation...pp. 71-77.

Plate XXVIII.

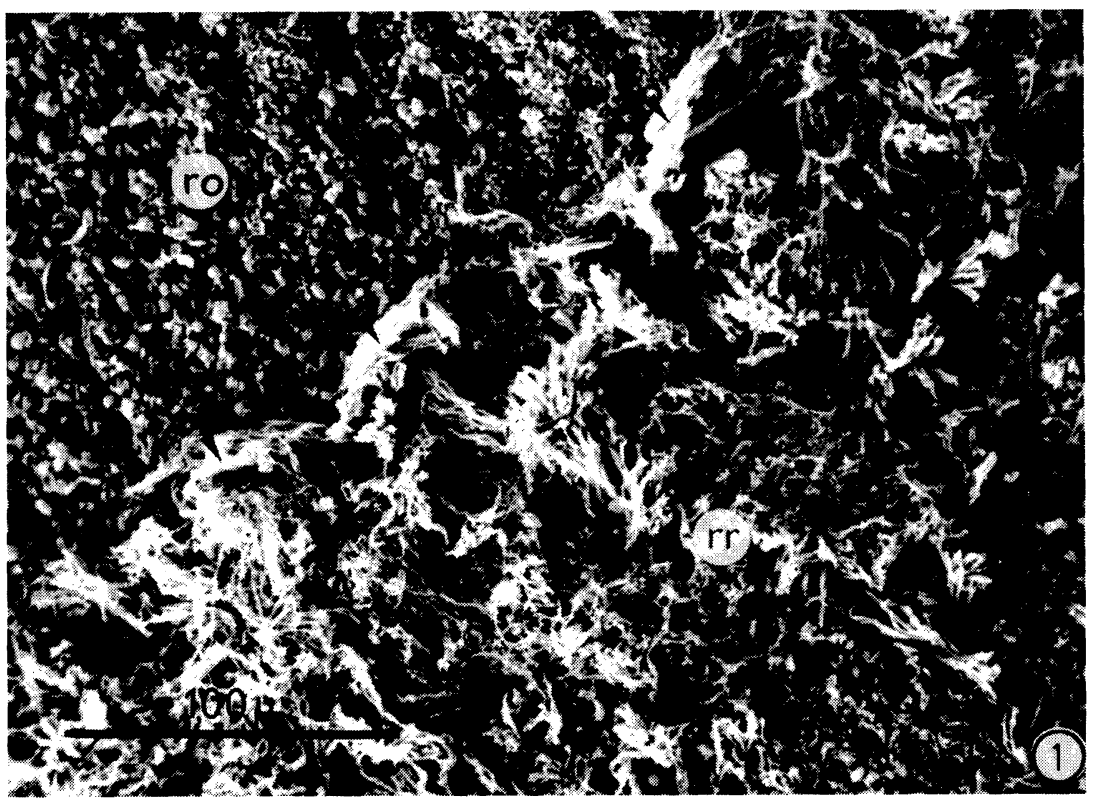

Fig. 1. The dividing line between the regio respiratoria (rr) and regio olfactoria (ro) in a 74-day old sheep foetus marked by numerous fibrous formations $(\rightarrow)$. Scanning electron microscopy (SEM), $\times 450$

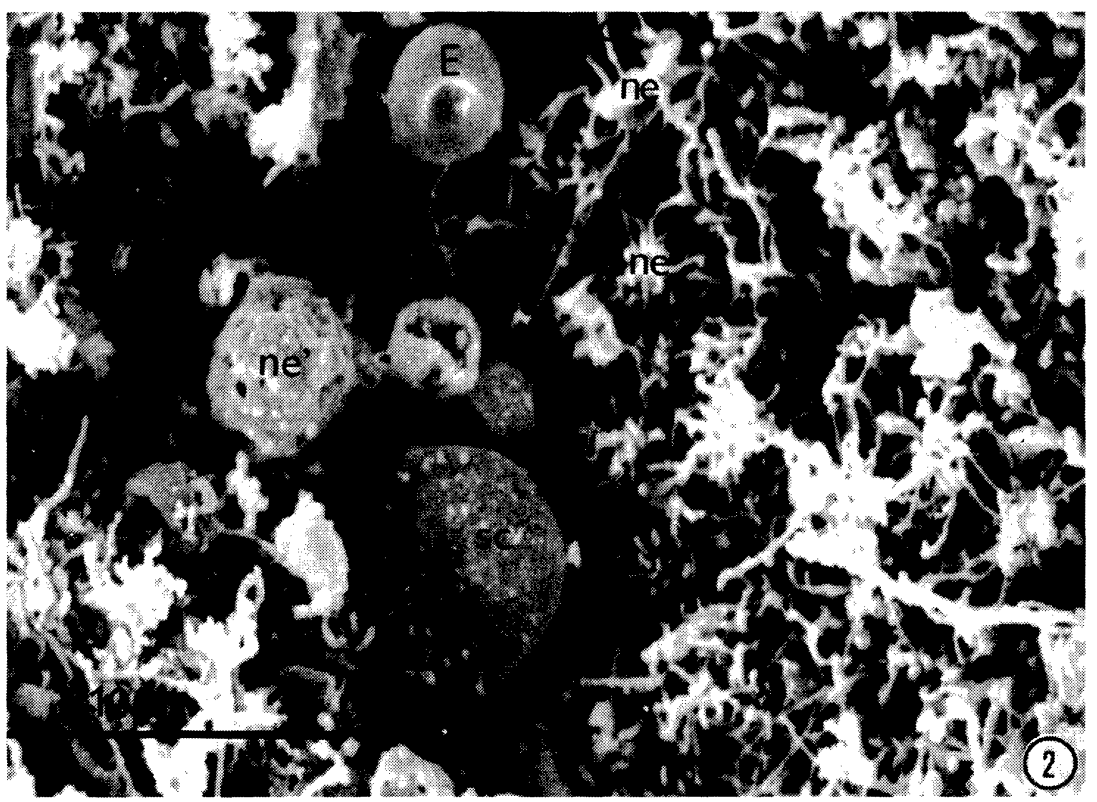

Fig. 2. Rostral part of the surface of the olfactory mucosa of a 74-day old sheep foetus. Olfactory endings (ne) with protruding cilia (c). Differentiating endings of the dendrite of the sensory cell (ne'). Sac-like apical segment of the sustentacular cell (sc), erythrocyte (E). (SEM), $\times 4500$ 


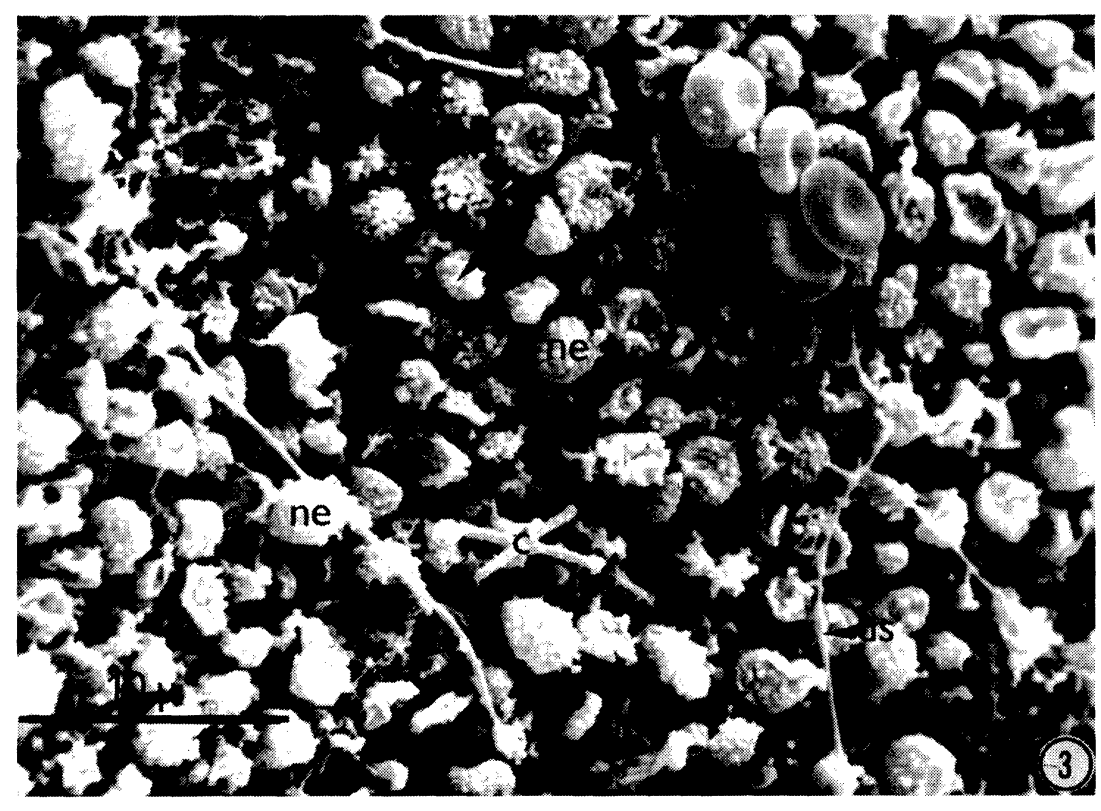

Fig. 3. Regio olfactoria of a 79-day old sheep foetus. The developing olfactory endings (ne) with small globular formations on the surface $(\rightarrow)$. Growing olfactory cilia (c), their distal segments (ds). (SEM) x 3500 .

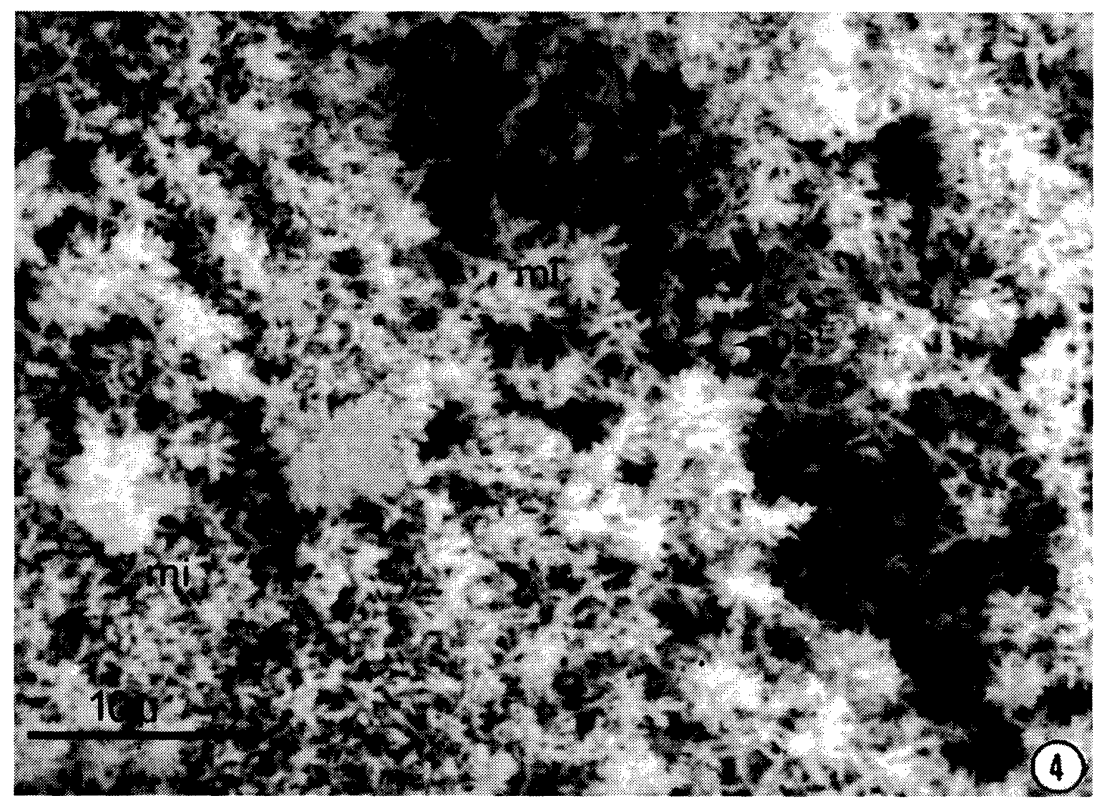

Fig. 4. Olfactory epithelium of a 1-day old lamb. Microvilli (mi) of sustentacular cells, olfactory endings (ne) with deflecting cilia, developing olfactory ending (ne'). (SEM) x 2700. 


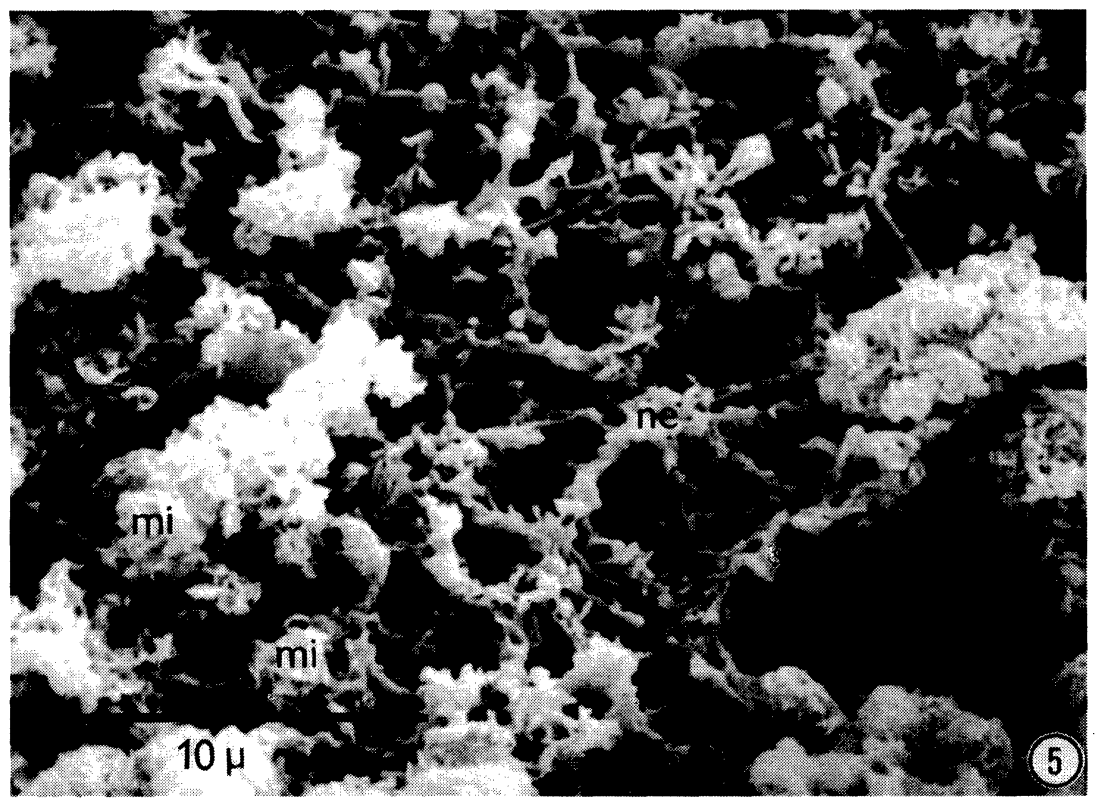

Fig. 5. The surface of the olfactory epithelium of a 30-day old lamb. Microvilli (mi) of sustentacular cells are enveloped in secretion. Olfactory endings (ne) with deflecting cilia (c). (SEM) x 4600 .

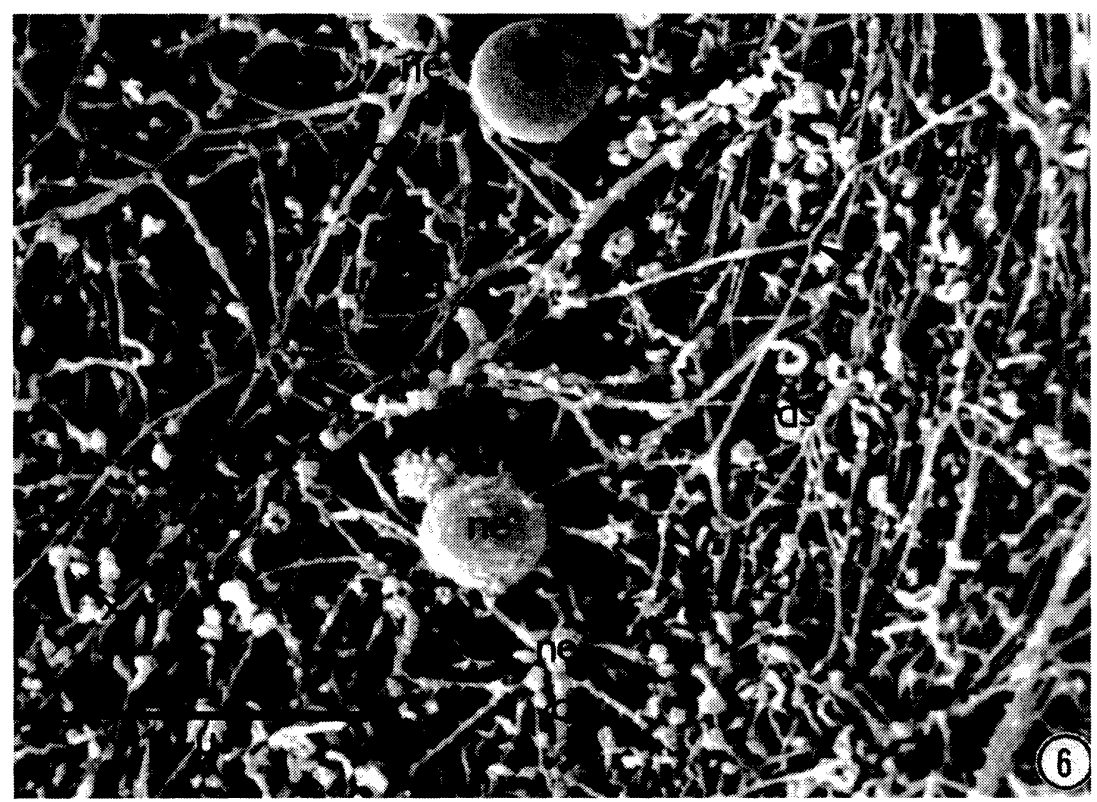

Fig. 6. Rostral segment of the olfactory mucosa of a 730-day old adult sheep. Olfactory cilia (c) deflecting from the olfactory ending (ne). Distal segments (ds), their contact $(\rightarrow)$. Globular formations among the cilia (x). Developing olfactory ending (ne'). Erythrocyte (E). (SEM) x 4700. 


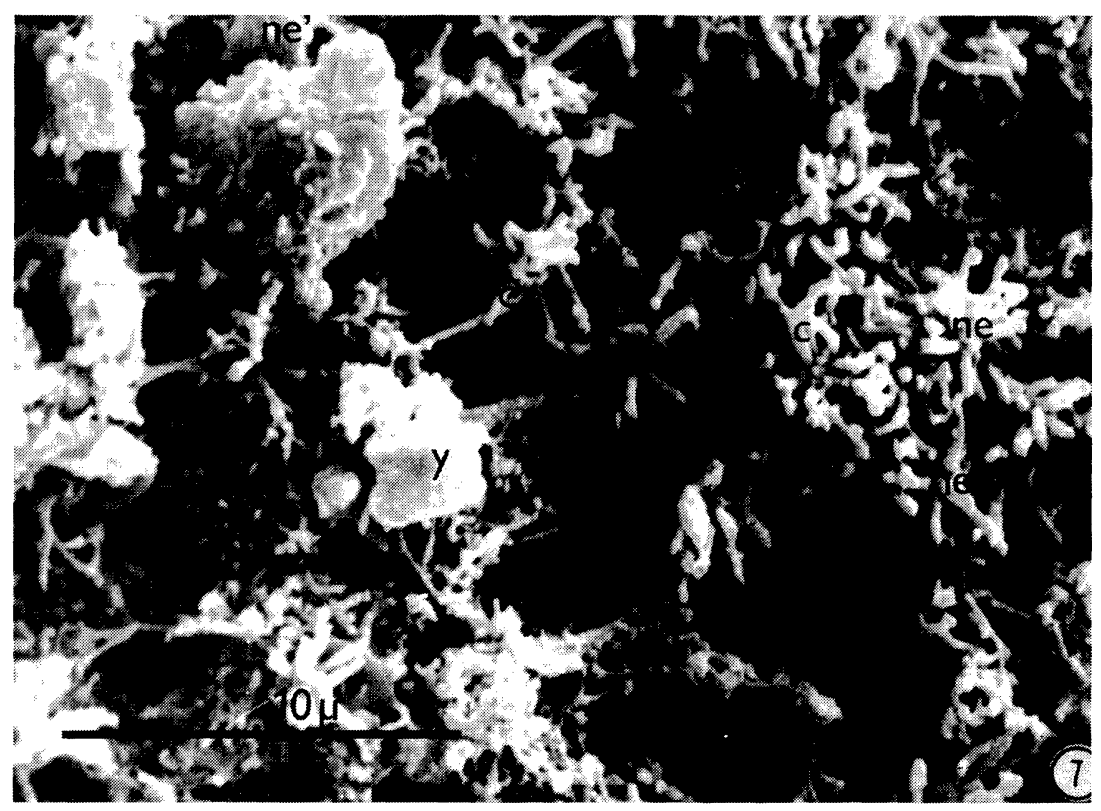

Fig. 7. Restructuralization of the caudal part of the surface of the regio olfactoria in a 730-day old adult sheep. Olfactory endings (ne) with deflecting cilia (c). Differentiating olfactory ending (ne'). Detritus (y). (SEM), x 5400. 


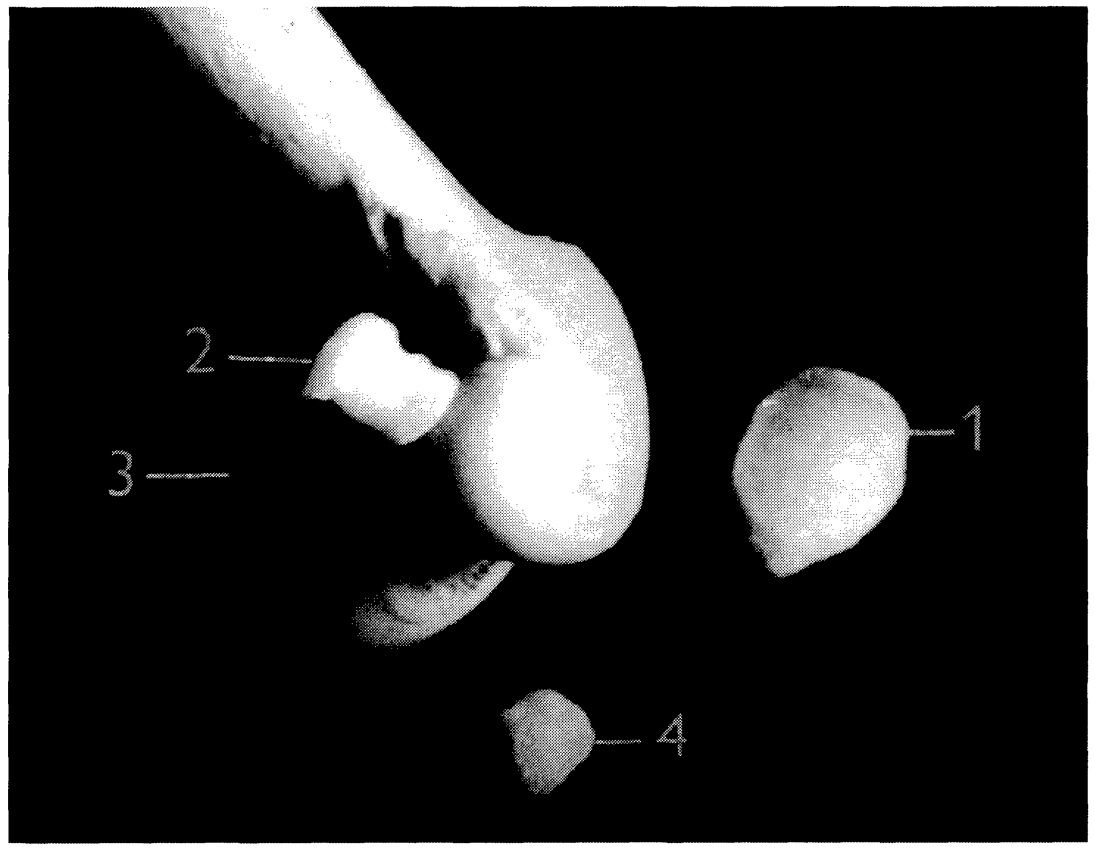

Fig. 2. The femur and sesamoid bones of the knee joint of the puma (aspectus caudolateralis). 1 - patella, 2 - os sesamoideum $\mathrm{m}$. gastrocnemii laterale, 3 - os sesamoideum $\mathrm{m}$. gastrocnemii mediale, 4-05 sesamoideum m. poplitei.

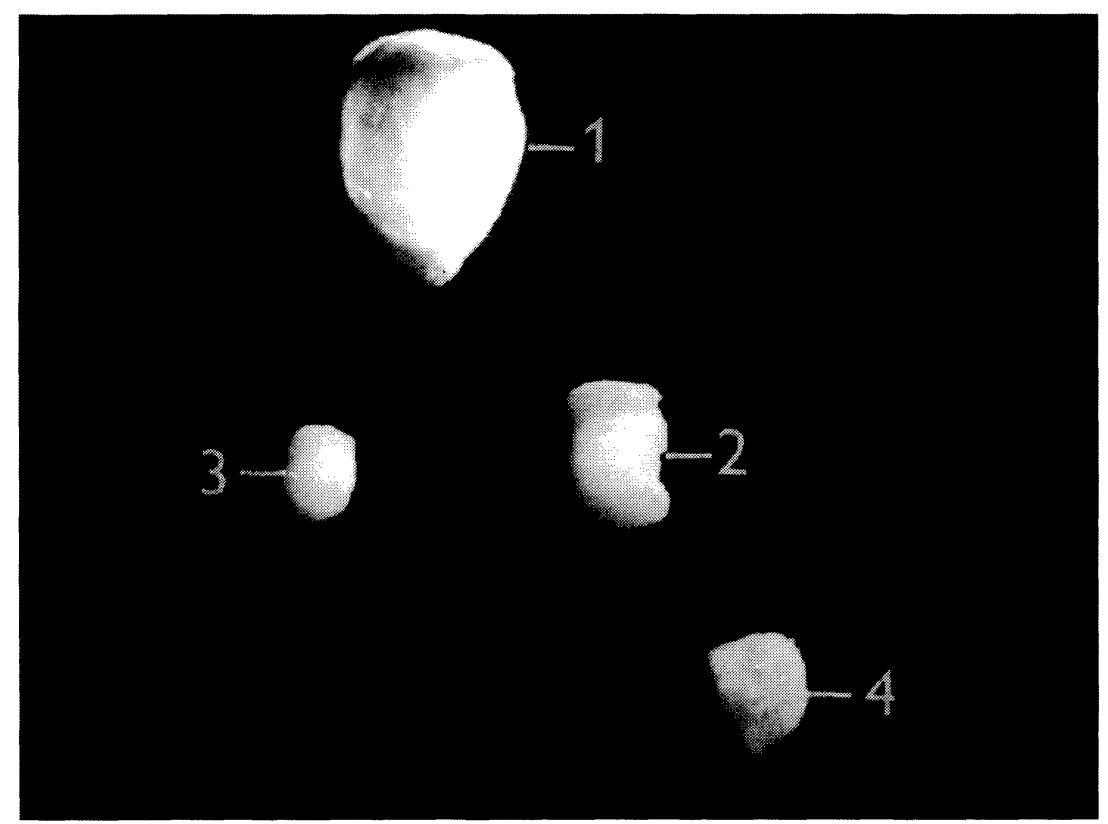

Fig. 3. Sesamoid bones of the knee joint of the puma (aspectus caudalis). 1 - patella, 2 - os sesamoideum $\mathrm{m}$. gastrocnemii laterale, 3 - os sesamoideum $\mathrm{m}$. gastrocnemii mediale, 4 - os sesamoideum m. poplitei. 